\title{
Microbiological assessment of cleanliness of surfaces and equipment in a children's operating theatre on the example of a selected hospital
}

\author{
Jolanta Gruszecka ${ }^{1,2, A-D, F} \oplus$, Dorota Gutkowska ${ }^{1, C-E, \oplus}{ }^{\oplus}$, Rafał Filip ${ }^{1,3, E, F} \oplus$ \\ ${ }^{1}$ Institute of Nursing and Health Sciences, Medical Faculty, University of Rzeszów, Poland \\ ${ }^{2}$ Clinical Department of Microbiology, Regional Clinical Hospital No. 2 in Rzeszów, Poland \\ ${ }^{3}$ Gastroenterology Clinic in the Centre for Comprehensive Treatment of non-specific Inflammatory Bowel Diseases, \\ Clinical Provincial Hospital No. 2 in Rzeszów, Poland
}

A - Research concept and design, B - Collection and/or assembly of data, C - Data analysis and interpretation,

$D$ - Writing the article, E-Critical revision of the article, F- Final approval of article.

Gruszecka J, Gutkowska D, Filip R. Microbiological assessment of cleanliness of surfaces and equipment in a children's operating theatre on the example of a selected hospital. Ann Agric Environ Med. 2019; 26(2): 249-251. doi: 10.26444/aaem/105899

\section{Abstract}

Introduction. The operating theatre is one of the most important places in a hospital. Due to the presence of numerous reservoirs of microorganisms and the invasiveness of surgical procedures it is necessary to ensure high hygiene standards in these locations.

Objective. The aim of the study was to carry out a qualitative assessment of the microbiological cleanliness of the surfaces and equipment in an operating theatre.

Materials and method. The results of microbiological tests of the surfaces and equipment of the Children's Operating Theatre in Clinical Provincial Hospital No. 2 in Rzeszów, southeast Poland, during 2007-2012 were reviewed retrospectively. Results and conclusions. For the analysis, a total of 1,819 swabs were collected, of which $1.05 \%$ were positive. Positive results were obtained mainly from samples taken from moist places (57.9\%). Among the microorganisms isolated, Gramnegative bacteria constituted the majority (57.9\%), Pseudomonas bacteria were found most frequently $(31,6 \%)$. Isolated microbes can be the etiological agent of nosocomial infections.

\section{$\checkmark$ Key words}

nosocomial infections, pathogenic microorganisms, microbiological cleanliness

\section{INTRODUCTION}

The operating theatre is one of the most important places in a hospital. Due to the invasiveness of the surgical procedures performed and the possibility of post-operative infections, it is absolutely necessary to ensure high standards of of hygiene in these locations.

Contaminated surfaces in the hospital environment, especially in the operating theatre environment, significantly increase the risk of pathogens responsible for infections associated with healthcare. In connection with the above, cleaning procedures, proper skin hygiene and effective disinfection are of key importance in preventing the spread of infections [1]. Positive results of microbiological monitoring of the operating theatre environment should always be the basis of verification of the sanitary and hygiene procedures in force at the facility [2].

\section{OBJECTIVE}

The aim of the study was a qualitative assessment of the microbiological cleanliness of the surfaces in a Children's Operating Theatre.

Address for correspondence: Jolanta Gruszecka, Institute of Nursing and Health Sciences, Medical Faculty, University of Rzeszów, Al. mjr. W. Kopisto 2a, 35-310 Rzeszów, Poland

e-mail: jagrusz@onet.pl

Received: 21.04.2018; accepted: 07.01.2019; first published:01.04.2019

\section{MATERIALS AND METHOD}

The results of microbiological tests of the surfaces and equipment in a Children's Operating Theatre carried out in 2007-2012 at the Clinical Provincial Hospital No. 2 in Rzeszów, southeast Poland, were reviewed retrospectively. Samples for testing were collected by swabbing from places where microbial contamination was most likely to be found and cleaning was most difficult. The checking of microbiological cleanliness did not include typical medical instruments. In accordance with the applicable methodology, the collected material was incubated in enriched broth at $37^{\circ} \mathrm{C}$ for 24 hours. After this time, cultures were prepared in blood agar and MacConkey agar. The dishes with blood agar and MacConkey medium were incubated for 24 hours. at $37^{\circ} \mathrm{C}$. In the case of growth on the media, Gram stained preparations were made, microorganisms were identified using BIOMERIEUX API tests. The drug resistance profile was examined by the disc diffusion method, or with aid of the VITEK2 automatic system (BIOMERIEUX) for identification and determination of the drug susceptibility of microorganisms $[3,4]$.

\section{RESULTS}

In 2007-2012, the microbiological cleanliness of the surfaces of a Children's Operating Theatre was studied, on average, once every quarter. In the analysed period, a total of 1,819 
smears were collected from dry and wet places. Between 220 363 samples were obtained annually. Of the 1,819 samples, only 19 bacterial strains were isolated, of which $11(57.9 \%)$ were Gram-negative and 8 (42.1\%) Gram-positive. Among of microorganisms isolated, Gram-negative bacteria accounted for the majority (57.9\%), and the most frequently found microorganisms were bacteria of the genus Pseudomonas (31.6\%) (Tab. 1).

Evaluation of the data obtained showed no seasonal variation in the range of microbiological contaminants.
Analysis of the profile resistance to antibiotics indicated a high level of sensitivity of the cultured microorganisms. Methicillin-resistant Staphylococcus aureus was isolated from one sample.

Positive results of microbiological tests were obtained mainly from samples taken from moist places (57.9\%). The remaining positive results $(42.1 \%)$ concerned smears obtained in dry places - Table 2.

Table 1. Swabs taken from the surfaces of the equipment of a Children's Operating Theatre in the years 2007-2012 and the microorganisms cultured

\begin{tabular}{|c|c|c|c|c|}
\hline Year & $\begin{array}{c}\text { Number of samples taken } \\
\mathrm{n}\end{array}$ & $\begin{array}{c}\text { Positive results } \\
\mathrm{n} / \%\end{array}$ & Cultured microorganisms & Drug sensitivity of microorganisms cultured* \\
\hline \multirow{4}{*}{2007} & \multirow{4}{*}{312} & \multirow{4}{*}{$4 / 1.3 \%$} & Enterobacter cloacae & GM(s), CAZ(s), CTX(s), CIP(s), SXT(s) \\
\hline & & & Serratia marcescens & CIP(s), GM(s), CAZ(s), SXT(s), TZP(s) \\
\hline & & & Pseudomonas stutzeri & CIP(s), TZP(s), PIP(s), CAZ(s), IPM(s) \\
\hline & & & Pseudomonas stutzeri & CIP(s), TZP(s), PIP(s), CAZ(s), IPM(s) \\
\hline \multirow{6}{*}{2008} & \multirow{6}{*}{336} & \multirow{6}{*}{$6 / 1.9 \%$} & Enterococcus faecalis & $A M(s), P(s), V A(s), G M(r), I P M(s)$ \\
\hline & & & Staphylococcus aureus & $\operatorname{SXT}(s), C M(s), E(s), P(s), O X(s)$ \\
\hline & & & Staphylococcus aureus MRSA & $\mathrm{SXT}(\mathrm{s}), \mathrm{CM}(\mathrm{r}), \mathrm{E}(\mathrm{r}), \mathrm{P}(\mathrm{r}), \mathrm{OX}(\mathrm{r})$ \\
\hline & & & Pseudomonas aeruginosa & CIP(s), TZP(s), PIP(s), CAZ(s), IPM(s) \\
\hline & & & Pseudomonas stutzeri & CIP(s), TZP(s), PIP(s), CAZ(s), IPM(s) \\
\hline & & & Pseudomonas stutzeri & CIP(s), TZP(s), PIP(s), CAZ(s), IPM(s) \\
\hline 2009 & 329 & $1 / 0.3 \%$ & Enterococcus faecalis & $A M(s), P(s), V A(s), G M(s), I P M(s)$ \\
\hline \multirow{3}{*}{2010} & \multirow{3}{*}{259} & \multirow{3}{*}{$3 / 1.1 \%$} & Pseudomonas aeruginosa & CIP(s), TZP(s), PIP(s), CAZ(s), IPM(s) \\
\hline & & & Acinetobacter junii & SXT(s), GM(s), CAZ(s), TZP(s), CIP(s) \\
\hline & & & Escherichia coli & CTX(s), TM(s), SXT(s), GM(r), AMC(r) \\
\hline \multirow{3}{*}{2011} & \multirow{3}{*}{363} & \multirow{3}{*}{$3 / 0.8 \%$} & Staphylococcus aureus & SXT(s), CM(s), E(s), P(s), OX(s) \\
\hline & & & Enterococcus faecalis & $\operatorname{AM}(s), P(r), V A(s), G M(s), I P M(s)$ \\
\hline & & & Acinetobacter spp. & $\operatorname{SXT}(r), G M(s), C A Z(s), T Z P(s), C I P(s)$ \\
\hline \multirow{2}{*}{2012} & \multirow{2}{*}{220} & \multirow{2}{*}{$2 / 0.9 \%$} & Enterococcus faecalis & $A M(s), P(s), V A(s), G M(s), I P M(s)$ \\
\hline & & & Enterococcus faecalis & $A M(s), P(s), V A(s), G M(s), I P M(s)$ \\
\hline Total & 1819 & $19 / 1.05 \%$ & & \\
\hline
\end{tabular}

* Legend: $r$ - resistant, $s$ - sensitive

AM-Ampicillin, AMC - Amoxicillin/Clavulanic acid, CAZ - Ceftazidim, CIP-Ciprofloxacin, CM - Clindamycin, CTX - Cefotaxim, E-Erythromycin, GM - Gentamicin, IPM - Imipenem, OX Oxacillin, P-Penicillin, PIP - Piperacillin, SXT-Trimethoprim/Sulfamethoxazole, TM-Tobramycin, TZP-Piperacillin/Tazobactam, VA-Vancomycin

Table 2. Type of surfaces where potentially pathogenic microorganisms were found

\begin{tabular}{|c|c|c|c|c|c|}
\hline \multicolumn{3}{|c|}{ Wet places } & \multicolumn{3}{|c|}{ Dry places } \\
\hline Surface & $\begin{array}{c}\text { Positive results of } \\
\text { microbiological tests } \\
\mathrm{n} / \% \text { of all positive results }\end{array}$ & $\begin{array}{l}\text { Microorgan-isms } \\
\text { cultured }\end{array}$ & Surface & $\begin{array}{c}\text { Positive results of } \\
\text { microbiological tests } \\
\mathrm{n} / \% \text { of all positive results }\end{array}$ & $\begin{array}{l}\text { Microorgan-isms } \\
\text { cultured }\end{array}$ \\
\hline $\begin{array}{l}\text { Wash basin } \\
\text { in the toilet }\end{array}$ & $6 / 31.6 \%$ & $\begin{array}{c}\text { Seratia marcescens } \\
\text { Pseudomonas aeruginosa } \\
\text { Enterococcus faecalis } \\
\text { Pseudomonas aeruginosa } \\
\text { Acinetobacter junii } \\
\text { E.coli }\end{array}$ & $\begin{array}{l}\text { Instrument cabinet } \\
\text { top }\end{array}$ & $2 / 10.5 \%$ & $\begin{array}{l}\text { Pseudomonas stutzeri } \\
\text { Enterococcus faecalis }\end{array}$ \\
\hline $\begin{array}{l}\text { Wash basin } \\
\text { for instruments }\end{array}$ & $1 / 5.2 \%$ & Enterobacter cloacae & Transport trolley & $1 / 5.2 \%$ & Pseudomonas stutzeri \\
\hline Soap dispenser lever & $2 / 10.5 \%$ & $\begin{array}{l}\text { Enterococcus faecalis } \\
\text { Enterococcus faecalis }\end{array}$ & $\begin{array}{l}\text { Cabinet for sterile } \\
\text { equipment }\end{array}$ & $3 / 15.8 \%$ & $\begin{array}{l}\text { Pseudomonas stutzerii } \\
\text { Pseudomonas stutzerii } \\
\text { Staphylococcus aureus }\end{array}$ \\
\hline- & - & & Tray & $1 / 5.2 \%$ & $\begin{array}{c}\text { Staphylococcus aureus } \\
\text { MRSA }\end{array}$ \\
\hline Total & $11 / 57.9 \%$ & & & $8 / 42.1 \%$ & \\
\hline
\end{tabular}




\section{DISCUSSION}

Infections in hospital are among the most complex problems related to the hospitalization of patients. They may be a consequence of lack of due diligence in the application of medical procedures, and improper organization of work at the facility [5].

As part of comprehensive measures to reduce the risk of nosocomial infections, it is justified to implement not only appropriate procedures for the decontamination of the hospital environment, but also methods allowing assessment of their effectiveness [6].

Cleaning and disinfection of surfaces and equipment in the operating block in the period under discussion was carried out manually by wiping, using of mops and cloths in accordance with the principle of single contact. Disinfection preparations were selected according to the hazard and type of disinfected area. Mainly solutions of preparations lasting up to 15 minutes were used, while complying with the parameters recommended by the manufacturer regarding concentration, time of operation and temperature.

The assessment of contamination of surfaces and equipment of the Children's Operating Theatre in 2007-2012 indicated sporadic shortcomings in the effectiveness of cleaning and disinfection, as evidenced by the positive results of the microbiological examination obtained in the case of $1.05 \%$ of samples taken. Surface contamination with pathogenic microorganisms should be taken as a signal of the need to check the effectiveness of cleaning and disinfection [7].

Qualitative analysis of the microflora isolated from the operating theatre environment showed that more than half of the positive results were Gram-negative bacteria, and the most frequently found microorganisms were rods of Pseudomonas. These bacteria are a common cause of nosocomial infections, both exogenous and endogenous $[8,9]$.

During the analysed period, microorganisms from the Enterobacteriaceae family and Gram-positive cocci were found sporadically in the collected samples. Microorganisms from the Enterobacteriaceae family can cause infections of various systems: primarily the urinary tract, digestive tract, and can also cause sepsis [10].

Gram-positive cocci (Enterococcus faecalis) are mainly opportunistic microorganisms, most enterococcal infections occur in immunocompromised patients [11].

The microorganisms Staphylococcus aureus very easily colonize the surface of the skin and mucous membranes, especially damaged ones. Staphylococcus aureus is a special threat for the immunocompromised [12].
The limitation of this study is the lack of quantitative microbiological examination of the surfaces. Hence, further studies are needed for a full characterization of the microflora.

\section{CONCLUSIONS}

The degree of microbiological contamination of the operating theatre surfaces and equipment was low, which indicates occasional shortcomings in the field of cleaning. Microorganisms that may constitute the etiological factor of nosocomial infections were isolated from the material collected for the study. Particularly worrying was the presence in the samples taken for analysis of methicillinresistant Staphylococcus aureus (MRSA).

\section{REFERENCES}

1. Antonowicz A. The risk of in-hospital infections of motor organs. Chir Narz Ruchu Ortop Pol. (Polish Orthopedics and Traumatology) 1982; XLVII, 1-2: 93-97.

2. Fleischer M, Rusiecka-Ziółkowska J, Jermakow K, Fleischer-Stępniewska K. Decontamination of the hospital environment and its importance in the prevention of infections related to hospitalization. Forum zakażeń (Forum of infections). 2015; 6(4): 217-225.

3. Grzybowski J, Reiss J. Practical medical and sanitary bacteriology. Warsaw: Bellona Publishing House, 2001.

4. Kępa M, Idzik D, Wojtyczka RD, Pacha J, Konik A, Brela R, et al. Assessment of microbiological cleanliness of the environment of the Operational Theatre of the Municipal Hospital No. 1 in Sosnowiec. Farmaceutyczny przegląd naukowy (Pharmaceutical scientific review). 2008; $4: 35$.

5. Wąsik D. Criminal law evaluation of infections. Prokuratura i prawo (Prosecutor and the law). 2017; 4: 40-57.

6. French GL, [ed.] A practical guide for monitoring the environment in hospitals. Warsaw: bioMerieux, 2014. pp. 27-37.

7. Fleischer M. Microbiological tests of the hospital environment. Zakażenia (Infections). 2003; 1: 18-23.

8. Witalis J. Gram-negative non-glucose-fermenting rod bacteria: Heczko PB, [ed.] Microbiology. Manual for nurses, midwives and paramedics. Warsaw: PZWL (National Institute of Medical Publications); 2006. pp. $132-136$.

9. Lalucat J, Bennasar A, Bosch R, Garcia-Valdes E, Palleroni NJ, et al. Biology of Pseudomonas stutzeri. Microbiol Mol Rev. 2006; 70(2): 510-547.

10. Chmielarczyk A, Surowiec J. Gram-negative rod bacteria from the family Enterobacteriaceae and Vibrionaceae. In: Heczko PB, [ed.] Microbiology. Manual for nurses, midwives and paramedics. Warsaw: PZWL (National Institute of Medical Publications); 2006. pp. 122-124.

11. Bulanda M, Romaniszyn D. Gram-positive cocci bacteria. In: Heczko PB, [ed.] Microbiology. Manual for nurses, midwives and paramedics. Warsaw: PZWL (National Institute of Medical Publications); 2006. pp. $108-116$.

12. Bulanda M. Gram-positive cocci bacteria. In: Heczko PB, Wróblewska M, Pietrzyk A, [eds.] Medical microbiology. Warsaw: PZWL (National Institute of Medical Publications); 2014. pp. 101-106.

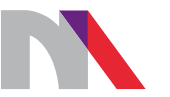

Ministry of Science and Higher Education

Republic of Poland

Generation of the DOI (Digital Object Identifier) - task financed under the agreement No. 618/P-DUN/2019 by the Minister of Science and Higher Education 